\title{
A comparative study of the relationship between the recovery of movement and the anatomical alignment in fractures around the elbow
}

\author{
Manish Raj, Simrat Pal Singh Gill*, Ajay Kumar Rajput, Santosh Kumar Singh
}

Department of Orthopaedics, Uttar Pradesh University of Medical Sciences, Saifai, Uttar Pradesh, India

Received: 24 May 2019

Revised: 19 June 2019

Accepted: 26 June 2019

\section{*Correspondence:}

Dr. Simrat Pal Singh Gill,

E-mail: simmygill@gmail.com

Copyright: () the author(s), publisher and licensee Medip Academy. This is an open-access article distributed under the terms of the Creative Commons Attribution Non-Commercial License, which permits unrestricted non-commercial use, distribution, and reproduction in any medium, provided the original work is properly cited.

\section{ABSTRACT}

Background: The injury around the elbow joint is a common condition in any age group, especially in children as a result of fall, during the course of a child's normal play. The aim of the present study was to study the relationship between the recovery of movements and the anatomical alignment in fractures around the elbow.

Methods: In the present study, 122 cases of fractures around elbow were included. The treatment with conservative or operative procedure depends on the surgeon concerned and his priorities. Sixty-six cases were treated conservatively, and 56 cases required operative intervention. At the time of follow up examination, cases were assessed as to the anatomical and functional point of view according to Flynn's criteria. We evaluated the reduction as per alignment in anteroposterior axis, lateral axis, and angulation. The patients were followed up for over 24 months. Results: Patients who had good anatomical alignment (grade A) showed 96.87\% satisfactory result as compared to the patient who had fair anatomical alignment (91.66\%) and poor anatomical alignment (54.54\%). Thus in grade A where alignment was up to 76 points, we had satisfactory result in $96.87 \%$ patients, where as in grade C where alignment was less than 50 points, the result in $45.5 \%$ of patients was poor.

Conclusions: Patients who had good anatomical alignment achieved, showed higher recovery of movement compared to the patient who had fair anatomical alignment and poor anatomical alignment.

Keywords: Recovery of movement, Anatomical alignment, Fractures around the elbow

\section{INTRODUCTION}

The main function of the elbow joint is mobility. However, due to the complicated articulation of the elbow joint, minor disturbances in anatomic alignment produces major disturbances in function. In the past, surgeons preferred the anatomical restoration of the joint over the physiological restoration of the joint. ${ }^{1,2}$ However, now a day, the functional restoration of the joint is more important than the anatomical restoration of the elbow joint. ${ }^{3,4}$ A perfect X-ray picture of the elbow joint showing excellent alignment may be stiff and useless, owing to either too prolonged immobilization or too strenuous treatment. However, if the bones are not in hairline alignment, but if the function is good, it will be considered a good result. ${ }^{5}$ There was no reported series in the literature that specifically deal with the study of the relationship between the recovery of movements and the anatomical alignment in fractures around the elbow. The aim of the present study was to study the relation between the recovery of movements and the anatomical alignment in fractures around the elbow.

\section{METHODS}

The present clinical work was conducted in the orthopaedic department of Uttar Pradesh University of medical sciences, after obtaining the permission from the 
ethical committee of the institute. The present study included 122 unselected cases of elbow injury treated between May 2012 to February 2016. Treatment depends upon the nature and stability of the individual fracture. Out of 122 cases, 66 cases $(54.1 \%)$ cases were managed non-operatively, and 56 cases $(45.9 \%)$ were managed operatively. Non-operative management includes only immobilization or closed reduction and immobilization by plaster of Paris cast or slab. Operative interventions were needed for displaced unstable fracture, unstable compound fracture, or displaced intraarticular fracture. The patients were followed up for over 24 months. The results were graded according to Flynn's criteria. ${ }^{6}$ Functions were graded as the restriction of the flexionextension arc and appearance as the change in the carrying angle.

Table 1: Grading of results. ${ }^{6}$

\begin{tabular}{|llll|}
\hline \multirow{2}{*}{ Results } & Rating & $\begin{array}{l}\text { Function } \\
\text { (loss of } \\
\text { flexion- } \\
\text { extension) } \\
\text { (degree) }\end{array}$ & $\begin{array}{l}\text { Change in } \\
\text { carrying } \\
\text { angle } \\
\text { (degree) }\end{array}$ \\
\hline \multirow{3}{*}{ Satisfactory } & Excellent & $0-5$ & $0-5$ \\
\cline { 2 - 4 } & Good & $5-10$ & $5-10$ \\
\cline { 2 - 4 } & Fair & $10-15$ & $10-15$ \\
\hline Unsatisfactory & Poor & Over 15 & Over 15 \\
\hline
\end{tabular}

Table 2: Numerical grading (point) system.

\begin{tabular}{|lllll|}
\hline Side shift & \multicolumn{1}{l|}{} \\
\hline Shift & Nil & $<25 \%$ & $25-50 \%$ & $>50 \%$ \\
\hline Points & 100 & 75 & 50 & 0 \\
\hline \multicolumn{5}{|l}{ Anterioposterior shift } \\
\hline Shift & Nil & $<25 \%$ & $25-50 \%$ & $>50 \%$ \\
\hline Points & 100 & 75 & 50 & 0 \\
\hline Axis deviation & & & & \\
\hline $\begin{array}{l}\text { Axis } \\
\text { deviation }\end{array}$ & Nil & $\begin{array}{l}10-20 \\
\text { degree }\end{array}$ & $\begin{array}{l}21-30 \\
\text { degree }\end{array}$ & $\begin{array}{l}>30 \\
\text { degree }\end{array}$ \\
\hline Points & 100 & 75 & 50 & 0 \\
\hline
\end{tabular}

To achieve an optimum result, anatomical alignment is considered to be a prime factor. By open reduction and internal fixation, we can achieve total anatomical alignment, but by conservative treatment, it may not be possible to achieve the same. To find out the effect of anatomical alignment and acceptable alignment (less anatomical), we evaluated the reduction as per alignment in anteroposterior axis, lateral axis, and angulation. ${ }^{6}$

The following work out had been done to calculate the final alignment, and evaluation was done by numerical grading (point system).

The mean of all three numerical values was calculated and regarded as the final alignment of the fracture fragments. ${ }^{6}$
The final alignment of the fracture fragments was divided into three grades according to the mean value of alignment achieved after treatment, as mentioned in the Table 3.

Table 3: Grading of anatomical alignment.

\begin{tabular}{|ll|}
\hline Grades & $\begin{array}{l}\text { The mean value of anatomical } \\
\text { alignment achieved }\end{array}$ \\
\hline Grade A & 100 to 76 \\
\hline Grade B & 75 to 50 \\
\hline Grade C & Less than 50 \\
\hline
\end{tabular}

\section{RESULTS}

In the present series of 122 cases, 66 cases were treated conservatively, and 56 cases required operative intervention. We had our criteria for selecting the patients for conservative and operative treatment. Treatment was applied to all patients in the present series, but only 110 cases were available for follow up examinations. At the time of follow up, examination cases were assessed as to the anatomical and functional point of view, according to Flynn's criteria (1974). The movement and the change of the carrying angle of each patient were recorded.

Table 4: Method of treatment applied.

\begin{tabular}{|lll|}
\hline $\begin{array}{l}\text { Treatment } \\
\text { method }\end{array}$ & Number & $\begin{array}{l}\text { Percentage } \\
(\%)\end{array}$ \\
\hline Non-operative & 66 & 54.1 \\
\hline Operative & 56 & 45.9 \\
\hline Total & 122 & 100.0 \\
\hline
\end{tabular}

Table 5: Number of cases according to anatomical alignment achieved.

\begin{tabular}{|lll|}
\hline $\begin{array}{l}\text { Anatomical } \\
\text { alignment }\end{array}$ & $\begin{array}{l}\text { Number of } \\
\text { cases }\end{array}$ & $\begin{array}{l}\text { Percentage } \\
(\%)\end{array}$ \\
\hline $\begin{array}{l}\text { Grade A } \\
\text { (100 to 76 points) }\end{array}$ & 68 & 55.7 \\
\hline $\begin{array}{l}\text { Grade B } \\
\text { (75 to 50 points) }\end{array}$ & 41 & 33.6 \\
\hline $\begin{array}{l}\text { Grade C } \\
\text { (Less than 50 } \\
\text { points) }\end{array}$ & 13 & 10.7 \\
\hline Total & 122 & 100.0 \\
\hline
\end{tabular}

Table 6: Result to different types of treatment used in elbow fractures.

\begin{tabular}{|c|c|c|c|c|}
\hline \multirow{2}{*}{ Result } & \multicolumn{2}{|c|}{ Type of fracture } & \multirow{2}{*}{ Total } & \multirow{2}{*}{$\%$} \\
\hline & Non-op. & Operative & & \\
\hline Excellent & 27 & 22 & 49 & 44.5 \\
\hline Good & 20 & 15 & 35 & 31.8 \\
\hline Fair & 11 & 06 & 17 & 15.5 \\
\hline Poor & 04 & 05 & 09 & 08.2 \\
\hline Total & 62 & 48 & 110 & 100.0 \\
\hline
\end{tabular}


Table 7: Relationship of anatomical alignment achieved to the recovery of movements at elbow joint.

\begin{tabular}{|c|c|c|c|}
\hline \multirow{2}{*}{$\begin{array}{l}\text { Anatomical } \\
\text { alignment }\end{array}$} & \multicolumn{3}{|c|}{ Recovery of movements } \\
\hline & Excellent & Satisfactory & Poor \\
\hline $\begin{array}{l}\text { Grade } A \\
\text { (100 to } 76 \text { points) }\end{array}$ & 32 & 30 & 01 \\
\hline $\begin{array}{l}\text { Grade } B \\
\text { (75 to } 50 \text { points) }\end{array}$ & 14 & 19 & 03 \\
\hline $\begin{array}{l}\text { Grade C } \\
\text { (less than } 50 \\
\text { points) }\end{array}$ & 03 & 03 & 05 \\
\hline Total & 49 & 52 & 09 \\
\hline
\end{tabular}

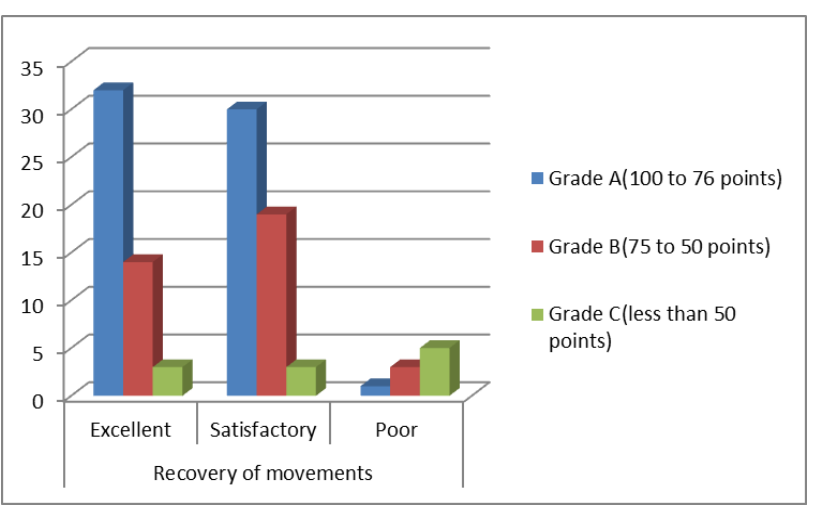

Figure 1: Relationship of anatomical alignment achieved to the recovery of movements at the elbow joint.

Out of 110 patients who were reviewed during their final follow up examination, $62(56.3 \%)$ patients had undergone the operative procedure as compared to 48 $(43.7 \%)$ patients who had managed non-operatively. After non-operative treatment, $43.54 \%$ patients showed the excellent result, $32.25 \%$ good, $17.74 \%$ fair and $6.45 \%$ poor. After operative treatment, $45.83 \%$ patients showed excellent result, $31.25 \%$ good, $12.5 \%$ fair, $10.41 \%$ poor. Sixty-three patients had good anatomical alignment (grade A), and 36 cases had fair alignment (grade B), and 11 cases had poor alignment (grade C). Patients who had good anatomical alignment (grade A) showed 96.87\% satisfactory result as compared to the patient who had fair anatomical alignment $(91.66 \%)$ and poor anatomical alignment $(54.54 \%)$. Thus in grade A where alignment was up to 76 points, we had satisfactory result in $96.87 \%$ where as in grade $\mathrm{C}$ where alignment was less than 50 points, the result in $45.5 \%$ of patients was poor.

\section{DISCUSSION}

The elbow is a link between the shoulder and the hand, functioning to position and stabilize the hand in space, as a load carrying joint, and as a fulcrum in the forearm lever. Pain-free mobility of the elbow joint is necessary for daily, recreational, and professional activities. The loss of mobility of the elbow secondary to injury is poorly tolerated because, unlike the other joints of the upper extremity, there is a lack of compensatory motions for the elbow in adjacent joints. ${ }^{5,7}$

The elbow is a complex hinge joint containing three different joints- humeroulnar, humeroradial and proximal radioulnar joints. It provide sufficient mobility to permit the upper limb to reach through wide range of flexion, extension and rotation, yet also enough stability to support the necessary gripping, pushing, pulling and carrying activities of daily life. Its stability is due largely to the shape and fit of the bones that make up the jointespecially the humeroulnar component - and this is liable to be compromised by any break in the articulating structures. The surrounding soft- tissue structures are also important, especially the capsular and collateral ligaments and, to a lesser extent the muscles.

The stability and biomechanics of the elbow joint have been examined in numerous studies of human anatomic specimens. Accurate restoration of the shape of the ulnotrochlear and radiocapitellar joints gives primary resistance to translational forces, and rotatory forces on the ulna are dissipated primarily by the coronoid against the anterior portion of the trochlea. Valgus stresses are resisted by the medial collateral ligament, and, to a less extent, the radial head. Varus stress is dissipated by articular congruity, the lateral collateral ligament and the capsule. ${ }^{8}$ Non-alignment in fractures around the elbow joint may be disabling. Loss of elbow motion is common because of articular deformity, intra- or extra-articular adhesions, or changes in the articular cartilage. ${ }^{9-11}$

Popular method of treatment of these fractures around elbow include close reduction, splint, cast or operative internal fixation of these fractures. ${ }^{12-14}$ Each treatment method had its advantages and disadvantages, but the recovery of movements is the ultimate goal of the treatment. Recovery of movements will depend on the anatomical alignment achieved either by closed reduction or by open reduction. Displaced fractures need anatomical alignment. As such, most of the patients of elbow injury will need open reduction. However, it has been found that even after closed reduction, acceptable alignment can be achieved with good recovery of movements. ${ }^{15-19}$ In the present study, we had tried to study the relationship between the recovery of movements and the anatomical alignment in fractures around the elbow. One hundred ten patients who were reviewed during their final follow up examination, 63 patients had good anatomical alignment (grade A), and 36 cases had fair alignment (grade B), and 11 cases had poor alignment. Patients who had good anatomical alignment (grade A) showed higher (96.87\%) satisfactory result as compared to the patient who had fair anatomical alignment $(91.66 \%)$ and poor anatomical alignment $(54.54 \%)$. There was not much difference between the results of conservative and operative treatment.

Except for nine patients in our present series, results in other patients (101 cases) were satisfactory (excellent, 
good and fair). These 9 patients showed poor results. Poor outcomes were observed mainly in those cases which came very late for operation, or there had either a history of massage or a history of repeated closed manipulation and also in cases complicated by postoperative new bone formation (myositis ossificans).

\section{CONCLUSION}

In present series, we found that recovery of movement is quite comparable as per as anatomical alignment achieved. Patients who had good anatomical alignment showed the higher satisfactory result as compared to the patient who had fair anatomical alignment and poor anatomical alignment.

Funding: No funding sources

Conflict of interest: None declared

Ethical approval: The study was approved by the institutional ethics committee

\section{REFERENCES}

1. Schemitsch EH, Tencer AF, Henley MB. Biomechanical evaluation of methods of internal fixation of the distal humerus. J Orthop Trauma. 1994;8:468.

2. Jupiter JB. Complex fractures of the distal part of the humerus and associated complications. Instructional Course Lecture. 1995;44:187-98.

3. McKee MD, Wilson TL, Winston L. Functional outcome following surgical treatment of intraarticular distal humeral fractures through a posterior approach. J Bone Joint Surg. 2000;82:1701.

4. Ring D, Bucholz RW, Court-Brown CM, Heckman JD, Tornetta. Rockwood and Green's Fractures in Adults. 2010;7:905-44.

5. Jupiter JB, Mehne DK. Fractures of the distal humerus. Orthopedics, 1992;15:825-33.

6. Flynn JC, Matthews JG, Benoit RL. Blind pinning of displaced supracondylar fractures of the humerus in children: Sixteen years' experience with longterm follow-up. J Bone Joint Surg Am. 1974;56:263-72.

7. Court-Brown CM, Aitken SA, Duckworth AD, Clement ND, McQueen MM: The relationship between social deprivation and the incidence of adult fractures. J Bone Joint Surg Am. 2013;95(6):321-7.

8. King GJW, Morrey BF, An KN. Stabilizers of the elbow. J Shoulder Elbow Surg. 1993;2:165-74.

9. Sim FH, Morrey BF. The elbow and its disorders. Philadelphia: WB Saunders; 1985: 340-354.

10. Ackerman G, Jupiter JB. Non-union of fractures of the distal end of the humerus. J Bone Joint Surg (Am). 1988;70:75-83.

11. Morrey BF. Post-traumatic contracture of the elbow: operative treatment, including distraction arthroplasty. J Bone Joint Surg (Am). 1990;72:60118.

12. Miller AN, Beingessner DM. Intra-articular distal humerus fractures. Orthop Clin North Am 2013;44:35-45.

13. Gupta N, Kay RM, Leitch K: Effect of surgical delay on perioperative complications and need for open reduction in supracondylar humerus fractures in children. J Pediatr Orthop. 2004;24:245.

14. Kumar R, Kiran E K, Malhotra R, Bhan S. Surgical management of the severely displaced supracondylar fractures of the humerus in children. Injury. 2002;33:517-22.

15. Yusof A, Razak M, Lim A. Displaced supracondylar fracture of humerus in children-comparitive study of the results of closed and open reduction. Med J Malaysia. 1998;53:52-8.

16. Oh CW, Park BC, Kim PT, et al. Completely displaced supracondylar humerus fractures in children: results of open reduction versus closed reduction. J Orthop Sci. 2003;8(2):37.

17. Shoaib M, Hussain A, Kamran H, Ali J. Outcome of closed reduction and casting in displaced supracondylar fracture of humerus in children. J Ayub Med Coll Abbottabad. 2003;15(4):23-5.

18. Bryce CD, Armstrong AD. Anatomy and biomechanics of the elbow. Orthop Clin North Am. 2008;39(2):141-54.

19. Lockard M. Clinical biomechanics of the elbow. J Hand Ther. 2006;19(2):72-80.

Cite this article as: Raj M, Gill SPS, Rajput AK, Singh SK. A comparative study of the relationship between the recovery of movement and the anatomical alignment in fractures around the elbow. Int $\mathrm{J}$ Res Orthop 2019;5:847-50. 